\title{
Malaria in Gold Miners in the Guianas and the Amazon: Current Knowledge and Challenges
}

\author{
Maylis Douine $^{1,2}$ (D) Yann Lambert ${ }^{1}$ (D) Lise Musset $^{3} \cdot$ Helene Hiwat $^{4}$ (D) Liana Reis Blume $^{5}$ (D) Paola Marchesini ${ }^{5}$ (D) \\ Gilberto Gilmar Moresco ${ }^{5}$ - Horace Cox ${ }^{6}$. Juan F. Sanchez ${ }^{7}$ (D) Leopoldo Villegas ${ }^{8,9}$. \\ Vincent Pommier de Santi ${ }^{10,11}$ (D) $\cdot$ Alice Sanna ${ }^{12} \cdot$ Stephen Vreden $^{13} \cdot$ Martha Suarez-Mutis $^{14}$ (iD
}

Published online: 21 March 2020

(C) The Author(s) 2020

\begin{abstract}
Purpose of Review Following Paraguay and Argentina, several countries from the Amazon region aim to eliminate malaria. To achieve this, all key affected and vulnerable populations by malaria, including people working on gold mining sites, must be considered. What is the situation of malaria in these particular settings and what are the challenges? This literature review aims to compile knowledge to answer these questions.

Recent Findings The contexts in which gold miners operate are very heterogeneous: size and localization of mines, links with crime, administrative status of the mines and of the miners, mobility of the workers or national regulations. The number of malaria cases has been correlated with deforestation (Brazil, Colombia), gold production (Colombia), gold prices (Guyana), or location of the mining region (Peru, Colombia, Venezuela, Guyana). The burden of malaria in gold mines differs between territories: significant in Guyana, French Guiana, or Venezuela; lower in Brazil. Although Plasmodium vivax causes $75 \%$ of malaria cases in the Americas, $P$. falciparum is predominant in several gold mining regions, especially in the Guiana Shield. Because of the remoteness from health facilities, self-medication with under-the-counter antimalarials is frequent. This constitutes a significant risk for the emergence of new $P$. falciparum parasites resistant to antimalarial drugs.

Summary Because of the workers' mobility, addressing malaria transmission in gold mines is essential, not only for miners, but also to prevent the (re-)emergence of malaria. Strategies among these populations should be tailored to the context because of the heterogeneity of situations in different territories. The transnational environment favoring malaria transmission also requires transborder and regional cooperation, where innovative solutions should be considered and evaluated.
\end{abstract}

This article is part of the Topical Collection on Amazonian Diseases in Isolate Populations

Maylis Douine

mdouine@yahoo.fr

1 Centre d'Investigation Clinique Antilles-Guyane (Inserm 1424), Cayenne Hospital, Avenue des Flamboyants, BP 6006, 97306 Cayenne CEDEX, French Guiana

2 Epidemiology of Tropical Parasitoses, EA 3593, Université de Guyane, Cayenne, French Guiana

3 Laboratoire de Parasitologie, Centre National de Référence du Paludisme, Institut Pasteur de la Guyane, Cayenne, French Guiana

4 National Malaria Program, Ministry of Health, Paramaribo, Suriname

5 Malaria Technical Group, Vector Transmissible and Zoonotic Diseases Coordination, Ministry of Health, Brasilia, Brazil

6 National Malaria Program, Ministry of Public Health, Georgetown, Guyana
Department of Parasitology, U.S. Naval Medical Research Unit No.6 (NAMRU-6), Lima, Peru

8 International Development, Global Development One, Silver Spring, MD, USA

9 Asociacion Civil Impacto Social (ASOCIS), Tumeremo, Bolivar, Venezuela

10 French Armed Forces Center for Epidemiology and Public Health (CESPA), Marseille, France

11 Aix Marseille Univ, IRD, AP-HM, SSA, VITROME, IHU-Méditerranée Infection, Marseille, France

12 Health Regional Agency, Cayenne, French Guiana

13 Foundation for Scientific Research Suriname (SWOS), Paramaribo, Suriname

14 Laboratory of Parasitic Diseases, Institute Oswaldo Cruz/Fiocruz, Rio de Janeiro, Brazil 
Keywords Malaria $\cdot$ Gold mines $\cdot$ Mobile population · Amazon region · Guiana Shield · America

\section{Introduction}

"A world free of malaria": this is the vision carried by the World Health Organization (WHO) in the Global technical strategy and targets for malaria 2016-2030 [1]. The targets are as follows: (i) to reduce malaria incidence and mortality by at least $90 \%$ by 2030, (ii) to eliminate the disease in at least 35 new countries, and (iii) to prevent its re-establishment in countries that were free of malaria in 2015. In the Americas, the number of malaria cases has been relatively constant over the past 10 years, from 814,000 in 2010 to 929,000 cases in 2018; but the epidemiological changes have been very different from one country to another $[2,3]$. While the number of cases has decreased down to $75 \%$ in several countries, it has increased in Peru, Guyana, Nicaragua, and Venezuela [3] (Fig. 1). Despite these challenges, malaria elimination is feasible: Paraguay was the first to be declared malaria free in the region of the Americas in 2018, followed by Argentina in 2019. Worldwide, among the 21 countries contending for elimination in 2020, seven are located in the Americas, including Suriname $[2,4]$ (Fig. 2). To achieve this goal, any human population at risk for malaria should be considered, including the most remote and neglected ones such as gold miners. What do we know about the situation of malaria in gold mining areas in the Amazon region? What are the related challenges in the malaria elimination framework in the Americas?

This review aims to provide an update of the situation of malaria in gold mining areas and to discuss the different strategies that can be implemented in each specific context. PubMed, SciELO, and Google Scholar databases were queried for any article published between January 1, 2014, and December 31, 2019, with keywords "Malaria," "gold," "mine," "Amazon," and "America." This search was then completed with data from the National Surveillance

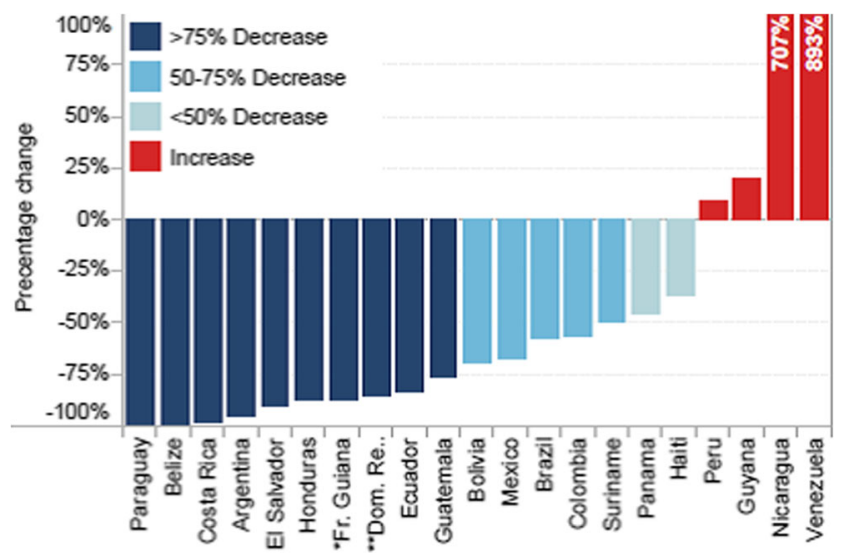

"French Guiana "* Dominican Republic

Fig. 1 Decrease in malaria morbidity by countries of the Americas, 2007-2017 (PAHO [3])
Systems, when available (sources: WHO, PAHO, Ministries of Health $(\mathrm{MoH})$ ). All countries and territories belonging to the Amazon region that reported malaria cases in gold mining areas over the same time period were considered, namely Brazil, Colombia, Guyana, French Guiana, Peru, Suriname, and Venezuela, even though the mining areas themselves might not all be located strictly in the Amazon forest.

\section{Gold Mines in the Amazon: Context and Health Impact Diseases}

The Amazonian subsoil is rich in gold, especially in the Guiana Shield. While this wealth can be a factor of economic growth, the exploitation of this subsoil generally benefits few people and has large negative effects on the environment, society, and health [5].

The socioeconomic situation of gold mining in the Amazon is heterogeneous. The administrative status-legal versus illegal-depends on the economic policy of each country and generally correlates with the exploitation type and with the size of the mines. The small-scale gold mining mainly refers to "mining that is labor intensive, makes use of simple (including artisanal) technology and limited mechanization, [...] mostly informal" [6]. Legal exploitation is more industrial. The proportion of these two mining statuses varies greatly from one country to the other (Table 1) [7-17].

Gold mining in general is one of the most destructive industries in the world [18]. If both legal and illegal gold mining practices have environmental consequences with ecosystem destruction and pollution of land and water, illegal gold mining ignores de facto the requirements and restrictions that condition legal exploitation and is thus even more catastrophic [19, 20]. Although prohibited in many countries, mercury is largely used to amalgamate fine gold particles. This use of mercury, as well as naturally occurring mercury released by mining, has dramatic consequences such as accumulation in fish and intoxication of fish consumers, particularly Native Americans [21]. Gold production is linked not only to gold prices but also to politicaleconomic de-structuring [8]. In fact, mining activity is often related to precariousness, insecurity, and even crime, especially in illegal contexts. In Peru and Colombia, the two countries with the largest cocaine production in the world, gold mining is used to launder money and the value of illegal gold exports now exceeds that of cocaine exports [22]. At the present time, most of the illegal mines in Colombia are controlled by the Revolutionary Armed Forces of Colombia (FARC-EP) [20]. Human rights are often violated with activities such as child labor and sexual exploitation [18]. 

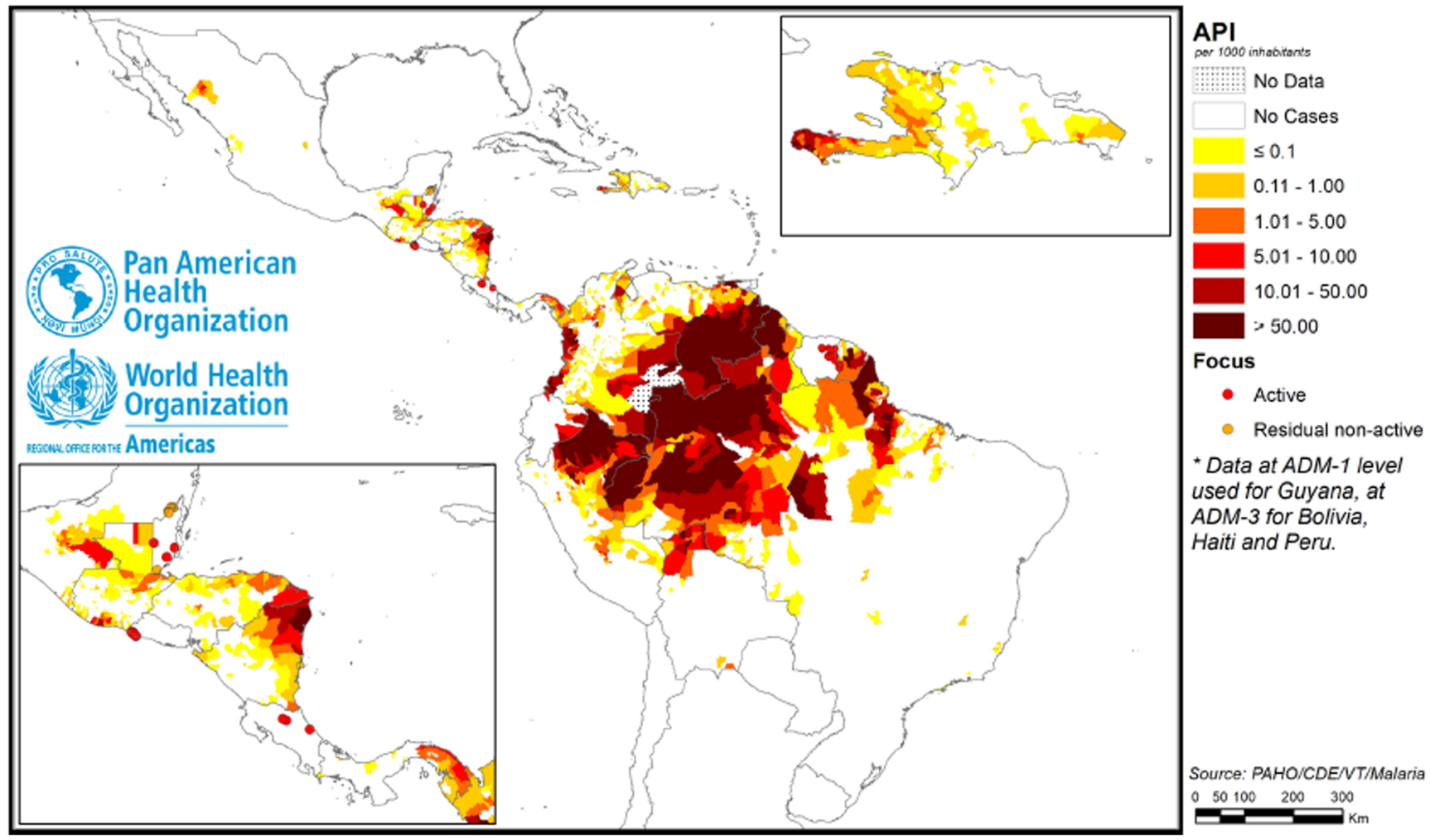

Fig. 2 Malaria by Annual Parasite Index (API) at the second administrative level in the Americas, 2017 (PAHO [3])

In this context, the disease burden is heavy for people working in the gold mining sector. The active gold miner population is estimated at 800,000 persons in the Amazon (Table 1), to which must be added people who gravitate around them such as logisticians, cooks, commercial traders, or gold miners' families $[6,11,15]$. Health facilities are rare or even absent not only from illegal sites, but also in legal mines []. The remoteness of gold mining sites, the cost of traveling, and the administrative situation hamper access to care. Gold miners suffer from a wide range of ailments such as intestinal parasitic disorders, cutaneous leishmaniasis, musculoskeletal pains, or hypertension $[11,23]$. However, malaria seems to be the main disease linked to gold mining [11, 24, 25]. Indeed, gold mining favors the proliferation of malaria vectors through deforestation, although this can be reversed in the event of massive deforestation by destroying the ecosystem of certain vectors [20, 25-27]. Different species of Anopheles incriminated in malaria transmission are found in gold mining areas, mainly A. darlingi, A. marajoara, A. nuneztovari, and A. albimanus $[5,20,28]$. Gold miners work and live outdoors, often in camps without walls, and are thus exposed to mosquito bites for long periods of time, by day and at night $[8,29]$. The use of mosquito net is scarce for several reasons: nets can be unavailable or miners may find them uncomfortable or useless [30].

All these elements - poverty, illegality, and remotenessadded to a political burden of this issue, such as transnational dilution of responsibility for this migrant population, making gold miners a particularly neglected population.

\section{Gold Miners: a Key Population for Malaria Transmission in the Amazon}

\section{Indirect Data: Correlation Studies}

\section{Deforestation and Number of Malaria Cases}

In the Amazonian part of Brazil, between 2009 and 2015, each new square kilometer of deforestation was associated with 27 new cases of malaria [31]. A recent work that studied the spatial spread of malaria and "economic frontier" expansion in the Brazilian Amazon concluded that recent malaria cases were concentrated in the most remote areas characterized by economical projects including deforestation fronts [32]. In Colombia, the Annual Parasitic Incidence (API) for malaria was shown to increase according to the surface of illegally mined area $[20,33]$.

\section{Gold Production and Number of Malaria Cases}

In Colombia, $69 \%$ of the variation in the number of malaria cases between 2010 and 2013 was linked to gold production. Two groups of mining districts were identified: those with 
high gold production methods, large numbers of malaria cases and high APIs, and those with low gold production and a low number of malaria cases [5]. A similar conclusion was found in Madre de Dios region in Peru in 2001-2012, where the number of malaria cases per month had a strong association with the amount of extracted gold, but a weak association with the average gold prices [13]. In Brazilian Amazon, the risk of malaria differs with the type of mining: the API in 2013 in municipalities with illegal mining activities was about 20.8 to 22.3 , while that in areas with industrial legal mining was between 0.2 and 0.5 [32]. In Guyana, the number of malaria cases is correlated with gold price and therefore the extent of mining activities (unpublished data).

\section{State-Level Data From Surveillance Systems}

National malaria control programs monitor malaria indicators, including cases and deaths. In Venezuela, gold miners account for an estimated 47 [8] to $80 \%$ of malaria cases [17] (Table 1). There, gold mining has been associated with high malaria incidence in specific municipalities such as Sifontes (Bolivar state) where mining activity is the most important occupational risk factor [8]. In Brazil, gold miners contribute about 6 to $7.6 \%$ of the total cases, with heterogeneity between regions $[8$, 9]. In the specific municipality of Itaituba (Pará state), miners represented $53.3 \%$ of the total malaria cases between 2011 and 2015 [34]. In Brazilian municipalities where mining is a central economic activity, malaria appeared as an occupational disease especially in young men [34]. In Colombia, 89.3\% of malaria cases originated from the six regions with the highest gold mining activity $[5,35]$. In Peru, until 2015, health facilities located in areas of intense illegal gold mining (Madre de Dios region) reported 30 times more malaria cases than those in non-mining areas $[13,36]$. This region, in which gold mining is the main economic activity, had the third largest number of malaria cases in Peru despite being the least populated area [13]. In Guyana, 94\% of malaria cases in 2018 were from the four regions where inhabitants participate in gold mining and logging as their main economic activity [37]. In French Guiana, where the government is fighting against illegal gold mining, soldiers and gendarmes (police officers) intervening in mining areas are often affected by malaria and can be considered as a good sentinel group to monitor malaria in those settings [28, 38]. In Suriname, local transmission has almost disappeared and most of malaria cases are imported from mining camps in Guyana and French Guiana [14].

\section{Specific Data From Epidemiological Studies in Gold Miners}

Using polymerase chain reaction (PCR), the best tool to detect asymptomatic parasitemia, two studies in French Guiana assessed Plasmodium spp. carriage by active case detection in gold miners. In 2015, the overall prevalence of Plasmodium spp. was $22 \%$; the situation was heterogeneous depending on the mining site with prevalence figures ranging from $4 \%$ up to $48 \%$. A large proportion were asymptomatic: from 49 to $84 \%$ $[39,12]$.

\section{Parasitological Data: Plasmodium Species in Gold Mines}

On the scale of the American continent, $75 \%$ of malaria cases are caused by Plasmodium vivax [3, 8]. But in gold mining areas, $P$. falciparum seems more prevalent. In Colombia, $P$. vivax represents $68 \%$ of malaria cases recorded nationally while $P$. falciparum is highly prevalent $(46.7 \%)$ in the mining districts on the Pacific coast [5]. On the Guiana Shield, the incidence of $P$. falciparum has decreased in the general population to a minority level in Suriname as well as in French Guiana since $2005[14,40]$ but remains predominant in gold miners, representing 58.5 to $70.7 \%$ of the identified cases [39, 12]. At the border between French Guiana and Brazil, $40 \%$ of imported cases from French Guiana were due to P. falciparum [41]. In Brazil, while $P$. vivax is found in $90 \%$ of malaria cases, $P$. falciparum typically predominates in newly opened settlements, being then progressively replaced by $P$. vivax in later stages [42]. In 2013, almost $40 \%$ of malaria cases originating from mining areas were caused by P. falciparum, compared with $16 \%$ of the total cases from other areas of Brazil [43]. In Guyana, P. falciparum represents $42 \%$ of the cases [37]. In Venezuela and Peru, the link between gold mining and P. falciparum is less obvious: P. vivax is responsible for $75 \%$ of malaria cases in Venezuela among which $80 \%$ are gold miners [9]. In Peru, P. vivax causes $99 \%$ of malaria cases even in gold mining areas [13].

\section{Public Health Challenges}

\section{From Difficult Access to Care to the Risk of Selection for Resistance}

Mining areas are most often remote, especially illegal sites. Access to health facilities is difficult and leads gold miners to use antimalarial treatment as self-medication. In French Guiana in 2015, despite possible access to regular care, selfmedication was used by 52 to $59 \%$ of gold miners during their last malaria episode $[30,12]$. Treatment was directly bought on mining sites $(80.7 \%)$ or given by friends or family $(6.1 \%)$. The treatment course was with artemisinin-based combination therapies (ACT), but incomplete in 40\% [30, 12]. Selfmedication is also very frequent in Suriname [44] and in Guyana [37], where the quality of antimalarials (in public, private, and informal sectors) is substandard [45, 46]. 


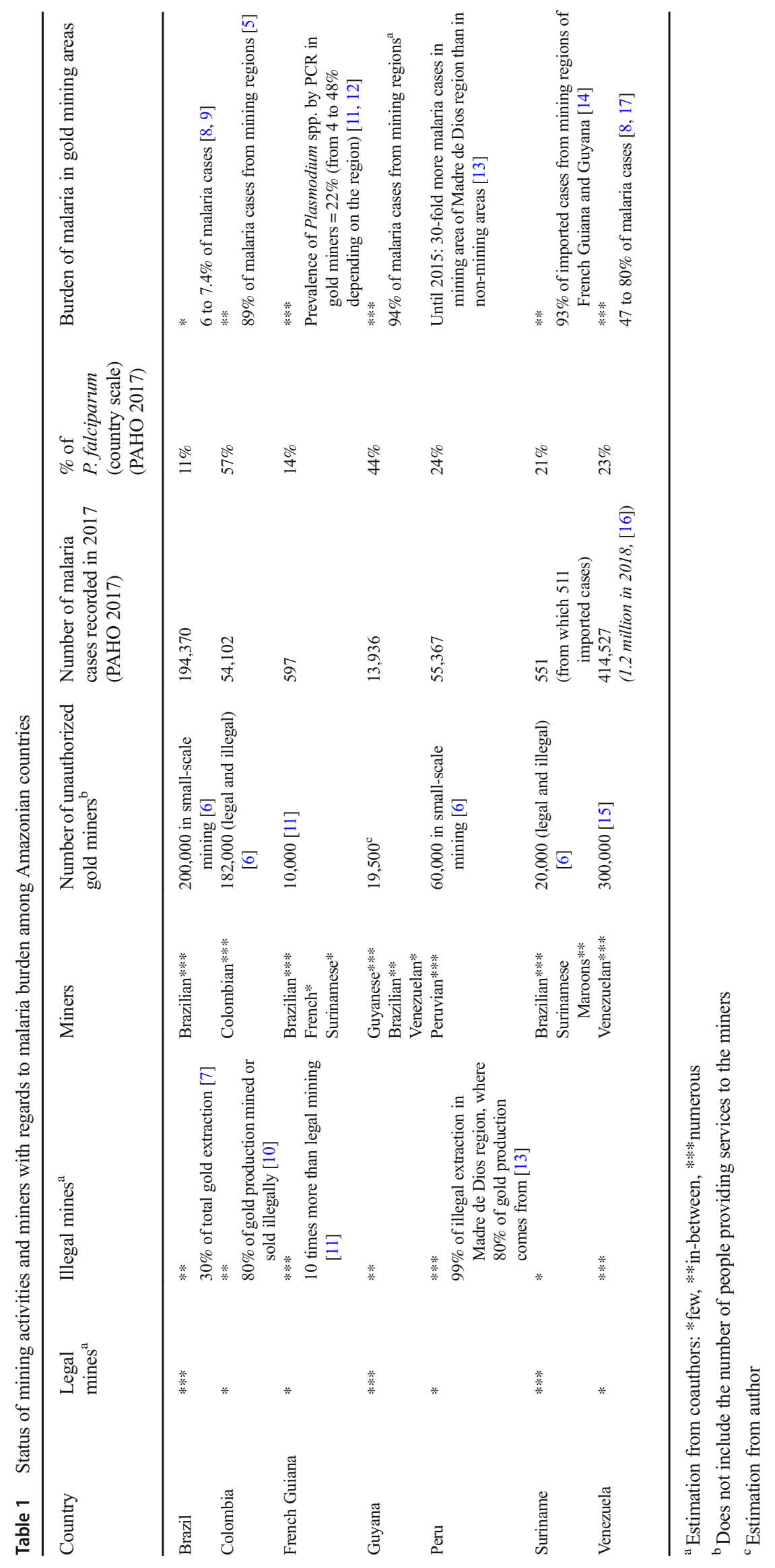


Socioeconomic crisis in Venezuela led to a deterioration of health facilities with shortages experienced in $88 \%$ of the hospitals. Those shortages also concern antimalarial drugs, which in turn give rise to the development of a black market [47]. In Peru, the MoH supervises access to antimalarial drugs, but controls in remote areas like gold mining areas are insufficient because of logistical challenges. Miners then have easy access to antimalarials in the private sector [13].

ACTs are the standard treatment in the whole Amazon region within the health care system or even the side market, with some variations in the partner drug. The frequent use of antimalarials bought from the private sector or black market, with poor adherence, raises the fear that drug resistance may emerge, especially artemisinin-resistant $P$. falciparum. National surveillance systems monitor Plasmodium spp. sensitivity in the region using different tools. ACT sensitivity can be detected in vivo with the persistence of parasites more than 3 days after treatment, or with a delayed parasite clearance time, as an indicator. In vitro, the survival rate of ring-stage parasites that have been exposed for $6 \mathrm{~h}$ to dihydroartemisinin is the best phenotyping method to identify decreased parasite susceptibility to dihydroartemisinin [48]. Finally, in 2013, some mutations in the pfK13 gene were shown to be associated with increased parasite clearance time in isolates from Southeast Asia [49]. However, surveillance of antimalarial drug efficacy in these mobile migrant populations is very challenging: getting blood samples from gold mining areas is not easy, and documenting associated clinical data even less. As a result, it is likely that an emergence of resistant parasites in the Amazon will remain undetected for some time. Proactive studies therefore seem necessary to document the susceptibility of parasites in these neglected populations.

In Guyana, a study in 2014 observed 2\% (95\%CI = 1-11) of day 3 positivity rate in patients from mining areas, without mutation in the propeller domain of the $p f k 13$ gene [37]. In 2016-2017, the mutation pfk13 C580Y was observed in the mining regions [50]. These mutant parasites were of the same genetic profile as the first five $p f k 13$ C580Y samples identified, in 2010, in the same region [50, 51]. In 2018-2019, the country conducted a new therapeutic efficacy study at two sites, Port Kaituma Region 1 and Georgetown Region 4, to evaluate the clinical impact of this mutation on therapeutic efficacy. However, no patient carrying mutant parasites was included. Nevertheless, introducing the pfk13 C580Y mutation in parasites from French Guiana, genetically close to those in Guyana, generated in vitro artemisinin resistance [50]. Currently, the status of this country is "suspected artemisinin resistance" [51]. In Suriname, despite a warning signal in 2011 in a study showing $31 \%$ of positive parasitemia at day 3 after artemether-lumefantrine treatment, no $p f k 13$ mutations have been observed [52, 53]. In French Guiana, in 2015 , none of the 32 samples collected from gold miners revealed mutations in the $p f k 13$ gene although one of the samples shows a slightly above-threshold survival rate with the ring-stage assay method [30, 48].

Knowledge, attitude, and practices (KAP) studies performed on the Guiana Shield showed that malaria symptoms and transmission modes are well known by gold miners. But even with good knowledge, only 16 to $36 \%$ of them declared having slept under a mosquito net the last night on the mining camp $[30,44]$. In Guyana, the KAP study showed that behaviors were more influenced by knowledge than by risk perception, contrary to that found in Suriname [44].

\section{The Mobility of Gold Miners as an Obstacle to Malaria Elimination}

In South-America, as well as in Southeast Asia, population movements across borders present a real challenge for malaria control and elimination. Several issues may be identified in a transborder context: delays in receiving diagnosis and treatment, improper health-seeking behavior and self-medication, lower levels of surveillance, and difficulties in coordinating malaria care and surveillance between countries [17, 54, 55]. This also leads to a major challenge in countries in the process of eliminating malaria or in those that already eliminated malaria: the prevention or reintroduction of cases through border areas or migrant populations $[5,55]$. Gold miners in the Amazon typically represent such a population: economic migrants, often with undocumented status, and highly mobile within the mining sites and across the borders [11].

The situation in Venezuela is a good illustration of the role of mining regions in the resurgence of malaria. This country is suffering a complex humanitarian emergency affecting all sectors. The economic crisis with hyperinflation (estimated at 10 million percent [56]) has been affecting the majority of the Venezuelan population. Emigration has increased significantly in recent years, reaching 4.6 million people from 2014 to 2019 [57]. Internally, population movements have been concentrated in illegal mining areas in Southern Venezuela, specifically in the Bolivar state where 60 to $70 \%$ of Venezuelan malaria cases originate. Venezuela experiences the biggest malaria epidemic of the twenty-first century in the region of the Americas, with the highest number of malaria cases and deaths. In 2018, civil society organizations have estimated the burden of malaria to be about 1.2 million cases [16] Consequently, malaria cases imported from Venezuela have been increasingly reported in Colombia, Guyana, Brazil, Suriname, Trinidad and Tobago, Chile, Argentina, Ecuador, and Peru, and represent the biggest spillover of malaria on the Western hemisphere [16].

Another example, even though it concerns relatively few people, documents the need to take these mobile people into account in public health strategies. In French Guiana, about ten thousand undocumented Brazilians from Maranhão and Para states have moved to work in gold mines directly 
overland from either Brazil or via Suriname. Among them, $68 \%$ reported having traveled from the mining site to one of the bigger cities of the Guiana Shield during the past year, and about 35\% having worked in another country than French Guiana in the past 3 years [11]. As many get infected at the mining camps in the French Guianese forest, they then are very likely to transmit malaria along their journey. Data of neighboring countries about imported cases speak for themselves: between 2004 and 2016, 90\% of malaria cases diagnosed in Suriname originated from French Guiana, which poses a major threat in its objective of eliminating malaria by 2020 [14]; and in Brazil, French Guiana represents the third country of origin of imported cases at the national scale after Venezuela and Guyana in 2019 [58]. In the Brazilian municipality of Oiapoque on the border with French Guiana, 32.9\% of malaria cases between 2008 and 2015 were imported from French Guiana [41].

\section{Gaps in the Literature}

The literature on malaria and gold mining in the Amazon is relatively scarce: on PubMed, "Malaria + gold + Amazon" yields 33 results, among which only eight were published in the past 5 years; "Malaria + gold mine + America" returns 55 results, among which 13 in the past 5 years. Most studies used data from surveillance systems but do not always include information about the occupation of the patients and the putative contamination place. In parallel, insightful "gray" information remains difficult to access. Most of these publications originate from the Guiana Shield, probably because in this region, other than elsewhere on the continent, malaria is almost exclusively linked to gold mining.

Study designs and methods are heterogeneous, which does not facilitate comparisons. Gold miners being mobile and living in remote - and sometimes unsecured - areas means that specific epidemiological studies are not easy to conduct, and malaria cases may not be recorded by the national surveillance systems [8]. These issues may lead to an underestimation of malaria cases associated with mining activity [8].

\section{Malaria and Gold Mining: What Strategies to Adopt?}

\section{A Need for Tailored Responses}

The contexts of malaria in gold mines are very heterogeneous, especially with regard to the administrative status of gold mines and gold miners (legal vs. illegal); the remoteness and accessibility of the mining camps; the political, economic, and security contexts; the robustness of the care system; the national regulatory issues; and the environmental protection strategy.

It is therefore important to tailor responses to the different epidemiological scenarios. According to $W H O$ global technical strategy 2016-2030 [1], the first pillar of a malaria control plan is the access to diagnosis and treatment within $48 \mathrm{~h}$ after the beginning of symptoms. This must be supported by the surveillance of malaria cases and Plasmodium spp. resistances, vector control, and prevention-which implies improving knowledge on malaria and its means of prevention. In addition, change in health care-seeking behavior is crucial considering the widespread use of self-medication with underthe-counter antimalarials. Strategies among gold miners cannot be implemented uniformly in the different territories but must be adapted to each specific context.

In Peru, the local MoH in the Madre de Dios region conducted mass drug administration (MDA) campaigns in illegal mining camps from 2011 to 2015: 1287 people received the standard treatment for $P$. vivax malaria infection (chloroquine 3 days + primaquine 7 days) in 122 mining camps [59]. Due to $10 \%$ of reported adverse events, the second phase of the intervention only focused on people who reported fever in the past 2 weeks. This strategy reduced dramatically the number of malaria cases, and was therefore discontinued when no longer needed. In addition, the $\mathrm{MoH}$ increased the activity of the Health Care for Excluded and Dispersed Populations (AISPED) in gold mining areas: these groups of health personnel visit communities in very remote areas, even those that are complicated and dangerous, and only accessible by foot (they walk for 20 to 25 days every month). During these trips, they conduct health assessments, malaria diagnosis, and treatment [60].

Suriname implemented a successful Global Fundsupported program called "Looking for Gold, Finding Malaria," targeting specifically gold mining areas with the training of "malaria service deliverers," which are the equivalent of community health workers, to test and treat malaria, free of charge, in all gold mining and logging communities. Combined with intensified control and surveillance activities in the Surinamese populations, this effort resulted in a $95 \%$ decrease of malaria cases in the country over the last 15 years $[4,14,61]$.

In French Guiana, the public health response faces many challenges. Regulations in this French department do not allow non-medical professionals to diagnose malaria and deliver treatment to any suspected malaria case. Additional barriers, such as the remoteness of mining camps and concomitant police operations against illegal gold mining, preclude the implementation of a program similar to the one successful in Suriname. Following the acknowledgment of these limitations by all partners, a tri-national operational research project, called Malakit, was developed by French Guianese, Surinamese, and Brazilian partners as a pilot to evaluate the 
efficacy of training and distribution of kits for self-diagnosis and self-treatment of malaria cases with the objectives to increase diagnosis and treatment coverage as well as treatment adherence $[62,63]$. These kits - containing three rapid diagnosis tests and one full course treatment of artemetherlumefantrine - are currently being delivered by health facilitators after a deep training session to gold miners working in French Guiana at border-crossing points in Suriname and Brazil [62].

In Guyana, the Ministry of Public Health has adopted a community-based approach for malaria case management. This initiative, piloted in 2016, involves capacity training of key persons at mining and logging sites to test and treat their pairs for malaria. It is currently being implemented at a large scale in the regions where malaria continues to be a public health concern. However, the high turnover of the resourcepersons and the remoteness of the mines complicate the sustainability and monitoring of the approach.

In Brazil, one important strategy to control malaria in remote areas is also to provide diagnosis and treatment by health workers in the closest mining community, or by trained people from the mining sites when feasible. Proactive case detection is performed where no professional routine diagnosis and treatment are available, with frequencies ranging from every month to every 3 months. Populations from areas situated in high-priority municipalities receive bed nets for malaria prevention.

In Colombia, there is no specific action currently targeting malaria in illegal gold mines. As most of them are controlled by the FARCs, political, military, and health issues are strongly intertwined, making the answer very difficult. Venezuela also illustrates the impact of the political, economic, and social contexts on malaria transmission and related responses. The presence of paramilitary groups (Colombian or Venezuelan) in regions impacted by illegal gold mines hampers the implementation of cost-effective interventions to key and affected populations [15].

\section{Importance of Cooperative Regional Monitoring and Response}

Malaria transmission and migration across borders also lead to diplomatic issues especially when addressing health concerns in populations otherwise subject to police prosecution. But malaria elimination will only be achieved with an effective collaboration and cooperation between countries. This cooperation should start with an efficient sharing of surveillance data on malaria cases and also resistance to antimalarial drugs, followed by bilateral coordination of the public health response in border areas. These data could be generated through programs to assess and monitor the malaria epidemiology in this target population, and through an overall improvement of national surveillance systems. For the Guiana Shield, sub- regional platforms could be created to address each one of the two malaria foci in the region: Venezuela-Guyana-Brazil and Suriname-French Guiana-Brazil. This regional, or subregional, surveillance system may provide a timely alert on variations of malaria epidemiology or emergence of antimalarial drug resistance. Although the risk of emergence of resistant $P$. falciparum has been the main concern until now, the increasing proportion of $P$. vivax cases leads to other challenges: the control of hypnozoites with the prevention of relapses and the emergence of choloroquine-resistant $P$. vivax [, 64-66]. The role of tafenoquine for hard-to-reach populations could be discussed for future strategies [67, 68].

Funding should therefore be made available to develop regional and national responses adapted to epidemiological scenarios and targeting key and vulnerable populations. In this endeavor, the importance of transnational support such as that provided by the Global Fund and European Union, as well as coordination and technical support from PAHO, must be underlined.

\section{Conclusion}

Mobile migrant populations mainly working in smallscale gold mining are a key population for the transmission of malaria in the Amazon. Targeting these populations is pivotal to prevent the (re-)emergence of (resistant) malaria in stable populations that are currently free of malaria. They deserve better malaria prevention, diagnosis, and treatment, and better provision of health care in general. Malaria elimination in the Amazon will be achieved only if no population is neglected. While implementing specific strategies, political and diplomatic aspects must not be underestimated. Indeed, policies that favor (or hamper) legal mining have an influence on malaria transmission and subsequent health responses. In many settings, gold miners do not have a good public image, especially because of ecosystem destruction, or conflicts with autochthonous populations. This hampers the funding and implementation of targeted health interventions.

The price of gold is still increasing and economic crises have worsened the situation in some countries like in Venezuela, pushing people to enroll in gold mining activities in the hope of a better future. Gold mining will continue, and with it, malaria transmission. To quote the WHO Director, "The choice before us is clear. If we continue with a 'business as usual' approach - employing the same level of resources and the same interventions - we will face near-certain increases in malaria cases and deaths" [69]. Innovative and targeted, context-specific strategies among gold miners are thus needed to fight malaria in the Amazon Region. 
Compliance with Ethical Standards The views expressed in this article are those of the author and do not necessarily reflect the official policy or position of the Department of the Navy, Department of Defense, nor the U.S. Government. (Juan F. Sanchez)

I am an employee of the U.S. Government. This work was prepared as part of my official duties. Title 17, U.S.C., $\$ 105$ provides that copyright protection under this title is not available for any work of the U.S. Government. Title 17, U.S.C., \$101 defines a U.S. Government work as a work prepared by a military Service member or employee of the U.S. Government as part of that person's official duties. (Juan F. Sanchez)

Open Access This article is licensed under a Creative Commons Attribution 4.0 International License, which permits use, sharing, adaptation, distribution and reproduction in any medium or format, as long as you give appropriate credit to the original author(s) and the source, provide a link to the Creative Commons licence, and indicate if changes were made. The images or other third party material in this article are included in the article's Creative Commons licence, unless indicated otherwise in a credit line to the material. If material is not included in the article's Creative Commons licence and your intended use is not permitted by statutory regulation or exceeds the permitted use, you will need to obtain permission directly from the copyright holder. To view a copy of this licence, visit http://creativecommons.org/licenses/by/4.0/.

\section{References}

1. World Health Organization. WHO | Global technical strategy for malaria 2016-2030. 2016 [cited 2018 Mar 28]. Available from: http://www.who.int/malaria/areas/global_technical_strategy/en/

2. World Health Organization World malaria report 2019. World Health Organization; 2019.

3. Pan American Health Organization. Report on the situation of malaria in the Americas - 2017. 2017 [cited 2019 Aug 16]. Available from: https://www.paho.org/hq/index.php?option=com topics \&view=article \&id=33\&Itemid=40757\&lang=en

4. van Eer ED, Bretas G, Hiwat H. Decreased endemic malaria in Suriname: moving towards elimination. Malar J. 2018 Jan 30;17(1):56.

5. Castellanos A, Chaparro-Narváez P, Morales-Plaza CD, Alzate A, Padilla J, Arévalo M, et al. Malaria in gold-mining areas in Colombia. Mem Inst Oswaldo Cruz. 2016;111(1):59-66.

6. Cremers L, Kolen J, Theije MEM de. Small-scale gold mining in the Amazon. The cases of Bolivia, Brazil, Colombia, Peru and Suriname. CEDLA; 2013 [cited 2019 Aug 16]. Available from: https://research.vu.nl/en/publications/small-scale-gold-mining-inthe-amazon-the-cases-of-bolivia-brazil

7. Heck C, Tranca J, editors. La realidad de la minería ilegal en países amazónicos: bolivia - Brasil - Colombia - Ecuador - Perú Venezuela. Lima, Perú: Sociedad Peruana de Derecho Ambiental (SPDA); 2014. $247 \mathrm{p}$

8. Recht J, Siqueira AM, Monteiro WM, Herrera SM, Herrera S, Lacerda MVG. Malaria in Brazil, Colombia, Peru and Venezuela: current challenges in malaria control and elimination. Malar J. 2017;16(1):273 .

9. Lapouble OM, Santelli A, Muniz-Junqueira M. Epidemiological situation of malaria in the Brazilian Amazon region, 2003 to 2012. Revista Panam Salud Pública. 2015;38:300-6.

10. Castro MC, Krieger GR, Balge MZ, Tanner M, Utzinger J, Whittaker M, et al. Examples of coupled human and environmental systems from the extractive industry and hydropower sector interfaces. Proc Natl Acad Sci. 2016;113(51):14528-35.
11. Douine M, Mosnier E, Le Hingrat Q, Charpentier C, Corlin F, Hureau L, et al. Illegal gold miners in French Guiana: a neglected population with poor health. BMC Public Health. 2017;18(1). Available from:). https://doi.org/10.1186/s12889-017-4557-4.

12. Pommier de Santi V, Djossou F, Barthes N, Bogreau H, Hyvert G, Nguyen $\mathrm{C}$, et al. Malaria hyperendemicity and risk for artemisinin resistance among illegal gold miners, French Guiana. Emerg Infect Dis. 2016;22(5):903-6.

13. Sanchez JF, Carnero AM, Rivera E, Rosales LA, Baldeviano GC, Asencios JL, et al. Unstable malaria transmission in the southern Peruvian Amazon and its association with gold mining, Madre de Dios, 2001-2012. Am J Trop Med Hyg. 2017;96(2):304-11.

14. Hiwat H, Martínez-López B, Cairo H, Hardjopawiro L, Boerleider A, Duarte EC, et al. Malaria epidemiology in Suriname from 2000 to 2016: trends, opportunities and challenges for elimination. Malar J. 2018 [cited 2019 Jun 10];17(1). Available from: https://doi.org/ 10.1186/s12936-018-2570-4

15. International Crisis Group. Gold and grief in Venezuela's violent south [Internet]. International Crisis Group; 2019 Feb [cited 2019 Dec 23]. (Latin America and Caribbean). Report No.: 73. Available from: https://www.crisisgroup.org/latin-america-caribbean/andes/ venezuela/073-gold-and-grief-venezuelas-violent-south

16. Villegas L, Torres MA. Malaria in Venezuela - situation report a resurgent epidemic in a complex humanitarian emergency. International Council of AIDS Service Organizations (ICASO) and Global Development One (GDO; 2019. Available from: http://icaso.org/wp-content/uploads/2019/08/Malaria-BriefsFINAL-August-2019.pdf

17. Ferreira MU, Castro MC. Malaria situation in Latin America and the Caribbean: residual and resurgent transmission and challenges for control and elimination. Meth Mol Biol. 2013;2019:57-70.

18. Wagner L. Organized Crime and illegally mined gold in Latin America [Internet]. Global Initiative against Transnational Organized Crime.; 2016 [cited 2019 Sep 16] p. 100. Available from: https://globalinitiative.net/organized-crime-and-illegallymined-gold-in-latin-america/

19. Dezécache C, Faure E, Gond V, Salles J-M, Vieilledent G, Hérault B. Gold-rush in a forested El Dorado: deforestation leakages and the need for regional cooperation. Environ Res Lett. 2017;12(3): 034013.

20. Villar D, Schaeffer DJ. Disarmament is the new war, gold is the new opium, and ecohealth is the historic victim. Environ Health Insights. 2019;13:1178630219862241.

21. Fréry N, Maury-Brachet R, Maillot E, Deheeger M, de Mérona B, Boudou A. Gold-mining activities and mercury contamination of Native Amerindian communities in French Guiana: key role of fish in dietary uptake. Environ Health Perspect. 2001;109(5):449-56.

22. The Guardian. Study claims illegal gold mining drives human rights abuses in Latin America. [Internet]. Policy Forum Guyana. 2016 [cited 2019 Oct 21]. Available from: http://www.policyforumgy. org/international/illegal-gold-mining-drives-human-rights-abuseslatin-america-claims-study/

23. Mosnier E, Carvalho L, Mahamat A, Chappert JL, Ledrans M, Ville $\mathrm{M}$, et al. Épidémies multiples dans des camps d'orpaillage en forêt amazonienne (Guyane française) en 2013 : quelles leçons pour l'accès aux soins et à la prévention? Bulletin Epidemiologique Hebdomadaire. 2015:181-9.

24. Fuller DO, Troyo A, Alimi TO, Beier JC. Participatory risk mapping of malaria vector exposure in northern South America using environmental and population data. Appl Geogr. 2014;48:1-7.

25. Jones RT, Tusting LS, Smith HMP, Segbaya S, Macdonald MB, Bangs MJ, et al. The impact of industrial activities on vector-borne disease transmission. Acta Trop. 2018;188:142-51.

26. MacDonald AJ, Mordecai EA. Amazon deforestation drives malaria transmission, and malaria burden reduces forest clearing: a retrospective study. Lancet Planet Health. 2019;3:S13. 
27. Laporta GZ. Amazonian rainforest loss and declining malaria burden in Brazil. Lancet Planet Health. 2019;3(1):e4-5.

28. Pommier de Santi V, Girod R, Mura M, Dia A, Briolant S, Djossou $\mathrm{F}$, et al. Epidemiological and entomological studies of a malaria outbreak among French armed forces deployed at illegal gold mining sites reveal new aspects of the disease's transmission in French Guiana. Malar J. 2016;15(1):35.

29. Pommier de Santi V, Dusfour I, de Parseval E, Lespinet B, Nguyen $\mathrm{C}$, Gaborit P, et al. Risk of daytime transmission of malaria in the French Guiana rain forest. Med Sante Trop. 2017;27:111-2.

30. Douine M, Lazrek Y, Blanchet D, Pelleau S, Chanlin R, Corlin F, et al. Predictors of antimalarial self-medication in illegal gold miners in French Guiana: a pathway towards artemisinin resistance. J Antimicrob Chemother. 2018;73(1):231-9.

31. Chaves LSM, Conn JE, López RVM, Sallum MAM. Abundance of impacted forest patches less than $5 \mathrm{~km}^{2}$ is a key driver of the incidence of malaria in Amazonian Brazil. Sci Rep. 2018 May 4 [cited 2019 Aug 8];8. Available from: https://www.ncbi.nlm.nih.gov/ pmc/articles/PMC5935754/

32. Souza PF, Xavier DR, Mutis MCS, da Mota JC, Peiter PC, de Matos VP, et al. Spatial spread of malaria and economic frontier expansion in the Brazilian Amazon. PLoS One. 2019;14(6): $\mathrm{e} 0217615$.

33. Rozo S. Unintended effects of illegal economic activities: illegal gold mining and malaria. Rochester: Social Science Research Network; 2016 [cited 2019 Aug 9]. Report No.: ID 2834623. Available from: https://papers.ssrn.com/abstract=2834623

34. Lopes TMR, da Silva VAMR, de Paula Souza e GRJ, Guimarães LHR. Situação epidemiológica da malária em uma região de Garimpo, na região da Amazônia brasileira, no período de 2011 a 2015. Revista Eletrônica Acervo Saúde. 2019;(25):e759-e759.

35. Feged-Rivadeneira A, Ángel A, González-Casabianca F, Rivera C. Malaria intensity in Colombia by regions and populations. PLoS One. 2018;13(9):e0203673.

36. Rosas-Aguirre A, Gamboa D, Manrique P, Conn JE, Moreno M, Lescano AG, et al. Epidemiology of Plasmodium vivax malaria in Peru. Am J Trop Med Hyg. 2016;95(6 Suppl):133-44.

37. Rahman R, Martin MJS, Persaud S, Ceron N, Kellman D, Musset $\mathrm{L}$, et al. Continued sensitivity of Plasmodium falciparum to artemisinin in Guyana, with absence of kelch propeller domain mutant alleles. Open Forum Infect Dis [Internet]. 2016;3(3). Available from: https://www.ncbi.nlm.nih.gov/pmc/articles/ PMC5047421/

38. Pommier de Santi V, Dia A, Adde A, Hyvert G, Galant J, Mazevet $\mathrm{M}$, et al. Malaria in French Guiana linked to illegal gold mining. Emerg Infect Dis. 2016;22(2):344-6.

39. Douine M, Musset L, Corlin F, Pelleau S, Pasquier J, Mutricy L, et al. Prevalence of Plasmodium spp. in illegal gold miners in French Guiana in 2015: a hidden but critical malaria reservoir. Malar J. 2016;15:315.

40. Musset L, Pelleau S, Girod R, Ardillon V, Carvalho L, Dusfour I, et al. Malaria on the Guiana Shield: a review of the situation in French Guiana. Mem Inst Oswaldo Cruz. 2014;109(5):525-33.

41. da Cruz FV, Peiter PC, Carvajal-Cortés JJ, Dos Santos PR, do Socorro MGM, Suárez-Mutis MC. Complex malaria epidemiology in an international border area between Brazil and French Guiana: challenges for elimination. Trop Med Health. 2019;47:24.

42. Ferreira MU, Castro MC. Challenges for malaria elimination in Brazil. Malar J. 2016;15(1):284.

43. Ministério da Saude. Plano de eliminação de malária no Brasil. Brasilia; 2016. Available from: https://portalarquivos2.saude.gov. br/images/pdf/2017/janeiro/04/Plano-eliminacao-malaria-pub.pdf

44. Heemskerk M, Duijves C. Gold miners' knowledge, attitudes and practices with regard to malaria in Suriname. Paramaribo; 2018 [cited 2019 Aug 16]. Available from: http://social-solutions.net/ data/index.php/rep/160-gold-miners-knowledge-attitudespractices-with-regard-to-malaria-in-suriname

45. Pribluda VS, Evans L 3rd, Barillas E, Marmion J, Lukulay P, Chang J. Were medicine quality and pharmaceutical management contributing factors in diminishing artemisinin efficacy in Guyana and Suriname? Malar J. 2014;13:77.

46. Hajjou M, Krech L, Lane-Barlow C, Roth L, Pribluda VS, Phanouvong S, et al. Monitoring the quality of medicines: results from Africa, Asia, and South America. Am J Trop Med Hyg. 2015;92(Suppl 6):68-74.

47. Page KR, Doocy S, Reyna Ganteaume F, Castro JS, Spiegel P, Beyrer C. Venezuela's public health crisis: a regional emergency. The Lancet. 2019;393(10177):1254-60.

48. Witkowski B, Amaratunga C, Khim N, Sreng S, Chim P, Kim S, et al. Novel phenotypic assays for the detection of artemisininresistant Plasmodium falciparum malaria in Cambodia: in-vitro and ex-vivo drug-response studies. Lancet Infect Dis. 2013;13(12):1043-9.

49. Ariey F, Witkowski B, Amaratunga C, Beghain J, Langlois AC, Khim N, et al. A molecular marker of artemisinin-resistant Plasmodium falciparum malaria. Nature. 2014;505(7481):50-5.

50. Mathieu L, Cox H, Early A, Mok S, Lazrek Y, Paquet J-C, et al. Local emergence and clonal propagation in eastern Amazonia of Plasmodium falciparum k13 C580Y mutants associated with in vitro artemisinin resistance. eLife. 2020; (in press).

51. Chenet SM, Akinyi Okoth S, Huber CS, Chandrabose J, Lucchi $\mathrm{NW}$, Talundzic E, et al. Independent emergence of the Plasmodium falciparum Kelch propeller domain mutant allele C580Y in Guyana. J Infect Dis. 2016;213(9):1472-5.

52. Adhin MR, Labadie-Bracho M, Vreden S. Gold mining areas in Suriname: reservoirs of malaria resistance? Infect Drug Resist. 2014;7:111-6.

53. Vreden SG, Jitan JK, Bansie RD, Adhin MR. Evidence of an increased incidence of day 3 parasitaemia in Suriname: an indicator of the emerging resistance of Plasmodium falciparum to artemether. Mem Inst Oswaldo Cruz. 2013;108(8):968-73.

54. Edwards HM, Canavati SE, Rang C, Ly P, Sovannaroth S, Canier L, et al. Novel cross-border approaches to optimise identification of asymptomatic and artemisinin-resistant Plasmodium infection in mobile populations crossing Cambodian borders. PLoS One. 2015;10(9):e0124300.

55. Wangdi K, Gatton ML, Kelly GC, Clements AC. Cross-border malaria: a major obstacle for malaria elimination. Adv Parasitol. 2015;89:79-107.

56. República Bolivariana de Venezuela and the International Monetary Fund. International Monetary Fund. [cited 2020 Jan 21]. Available from: https://www.imf.org/en/Countries/VEN

57. United Nations Refugee Agency. UNHCR: Venezuela situation. United Nations Refugee Agency. [cited 2020 Jan 21]. Available from: https://www.unhcr.org/venezuela-emergency.html

58. Ministério da Saude. Malária nas fronteiras e importada de outros países. Brasilia: Secretaria de Vigilância en Saude -SVS; 2019. Available from: https://public.tableau.com/profile/mal.ria.brasil\# !/vizhome/Mini_fronteira_1719/Painelpas

59. Sanchez J-F. Malaria epidemiology in the gold mines of Madre de Dios, Peru. In Atlanta; 2012.

60. Peruvian Ministry of Health. Norma Técnica de Salud de los Equipos de Atención Integral de Salud a Poblaciones Excluídas y Dispersas (Equipos AISPED). Ministerio de Salud; 2009 p. 47. (Dirección General de Salud de las Personas). Available from: http://bvs.minsa.gob.pe/local/DGSP/787_MS-DGSP250.pdf

61. Hiwat H, Hardjopawiro LS, Takken W, Villegas L. Novel strategies lead to pre-elimination of malaria in previously high-risk areas in Suriname, South America. Malar J. 2012;11:10.

62. Douine M, Sanna A, Galindo M, Musset L, Pommier de Santi V, Marchesini P, et al. Malakit: an innovative pilot project to self- 
diagnose and self-treat malaria among illegal gold miners in the Guiana Shield. Malar J. 2018 Dec [cited 2019 May 23];17(1). Available from: https://doi.org/10.1186/s12936-018-2306-5

63. Centre Hospitalier de Cayenne. Malakit Project. Malakit. [cited 2020 Jan 22]. Available from: https://www.malakit-project.org/

64. Douine M, Sanna A, Hiwat H, Briolant S, Nacher M, Belleoud D, et al. Investigation of a possible malaria epidemic in an illegal gold mine in French Guiana: an original approach in the remote Amazonian forest. Malar J. 2019;18(1):91.

65. Howes RE, Battle KE, Mendis KN, Smith DL, Cibulskis RE, Baird JK, et al. Global epidemiology of Plasmodium vivax. Am J Trop Med Hyg. 2016;95(6 Suppl):15-34.

66. Siqueira AM, Mesones-Lapouble O, Marchesini P, Sampaio VS, Brasil P, Tauil PL, et al. Plasmodium vivax landscape in Brazil: scenario and challenges. Am J Trop Med Hyg. 2016;95(6_Suppl):87-96.
67. Llanos-Cuentas A, Lacerda MVG, Hien TT, Vélez ID, Namaik-Larp C, Chu CS, et al. Tafenoquine versus primaquine to prevent relapse of Plasmodium vivax malaria. N Engl J Med. 2019;380(3):229-41.

68. Lacerda MVG, Llanos-Cuentas A, Krudsood S, Lon C, Saunders DL, Mohammed R, et al. Single-dose tafenoquine to prevent relapse of Plasmodium vivax malaria. N Engl J Med. 2019;380(3): 215-28.

69. World Health Organization, Global Malaria Programme. World malaria report 2017. 2017.

Publisher's Note Springer Nature remains neutral with regard to jurisdictional claims in published maps and institutional affiliations. 